\title{
Upaya Peningkatan Kemampuan Menulis Laporan Karya Ilmiah Remaja Melalui Pendekatan Kontekstual di SMA Manba’ul Ullum
}

\author{
Waqidatul Qoiriyah ${ }^{1)}$, Syahriani Syam ${ }^{2)}$ \\ Jurusan Teknik Informatika, Fakultas Teknik, Universitas Islam Syekh Yusuf, Jl. Mulana Yusuf No. 10 Tangerang \\ Banten 15118, Indonesia \\ 1)wqoiriyah@unis.ac.id \\ ssyam@unis.ac.id
}

\begin{abstract}
Abstrak. Penelitian ini bertujuan untuk meningkatkan kemampuan menulis laporan karya ilmiah remaja dengan menerapkan pendekatan kontekstual di SMA Manba'ul Ullum. Jenis penelitian yang dilakukan adalah penelitian tindakan kelas dengan dua siklus. Waktu penelitian berlangsung selama 3 bulan terhitung dari bulan September hingga November dengan sasaran 40 siswa. Terdapat dua jenis instrumen yang digunakan dalam penelitian yakni kuantitatif dan kualitatif.. Kuantitatif dilakukan melalui ujian akhir setelah siswa selesai mempresentasikan karya ilmiahnya., Sedangkan kualitatif dilakukan melalui observasi saat tindakan, wawancara, catatan lapanagan dan analisis dokumentasi. Observasi merupakan pengamatan yang dilakukan oleh observer dan penasehat. Catatan lapangan dilakukan oleh masing-masing peneliti, observer dan kepala sekolah (Sebagai supervisi).. Sebelum siklus nilai rata rata penulisan laporan 73, setelah diberikan tindakan (siklus 1) nilai rata rata penulisan laporan 78 namun peningkatan ini dirasa belum signifikan oleh peneliti, observer, dan kepala sekolah, maka dilakukan siklus kedua dan memperoleh nilai rata rata penulisan laporan 80,4. Dari data sebelumnya dapat disimpulkan bahwa penerapan pendekatan kontekstual berhasil dalam meningkatkan kemampuan siswa menulis laporan karya ilmiah remaja
\end{abstract}

Kata kunci : Kemampuan menulis laporan, karya ilmiah remaja, pendekatan kontekstual

\begin{abstract}
This research aims to improve the ability to write reports on adolescent scientific work by applying a contextual approach at SMA Manba'ul Ullum. This type of research is a classroom action research with two cycles. The study period lasted for 3 months from September to November with the target of 40 students. There are two types of instruments used in research, namely quantitative and qualitative. Quantitative is done through a final exam after students have finished presenting their scientific work. Observation is an observation made by an observer and advisor. Field notes were carried out by each researcher, observer and school principal (as a supervision). Before the cycle of the average score of report writing 73, after being given action (cycle 1) the average score of report writing was 78 but this increase was felt to be insignificant by the researcher, observer, and the principal, then the second cycle was carried out and obtained an average score of 80.4 report writing. From the previous data it can be concluded that the application of the contextual approach was successful in improving the ability of students to write reports on adolescent scientific work
\end{abstract}

Keywords: Ability to write reports, youth scientific work, contextual approaches

\section{Pendahuluan}

SMA Manba'ul Ullum merupakan salah satu sekolah di daerah tangerang yang memiliki program karya ilmiah bagi siswa siswinya di kelas 12 . Karya Ilmiah Remaja sudah berjalan sejak tahun pertama sekolah ini berdiri. Dalam praktiknya, banyak dijumpai siswa yang mengalami kesulitan dalam menulis laporan karya ilmiah. Hal ini ditunjukanoleh banyaknya koreksi dari penguji mengenai aspek tertulis dan pengembangan gagasan. Meskipun sudah berjalan sejak lama, sekolah ini memang belum memiliki panduan dalam penulisan karya ilmiah remaja baik sistematika maupun isi. Sejauh ini dalam penulisan KIR siswa siswi SMA Manba'ul Ullum hanya berpedoman pada contoh laporan pada penelitian sebelumnya yang belum tentu benar. Batasan bagian yang akan dibahas pun masih sangat terbatas. Fakta tersebut di analisa menjadi penyebab rendahnya nilai siswa dalam penulisan laporan karya ilmiah remaja. Pemahaman yang terbatas mengenai karya ilmiah dan cara menulis laporan mendorong untuk dilakukannya beberapa tindakan berbasis 
pendekatan kontekstual dalam meningkatkan kemampuan menulis laporan karya ilmiah siswa.

Secara deskriptif rendahnya kemampuan menulis laporan karya ilmiah remaja oleh siswa SMA Manba'ul Ullum ini ditunjukan oleh kesalahan dalam struktur tulisan, pengorganisasian tulisan, dan aspek mekanika penulisannya. Kesalahan dalam struktur tulisan berkaitan dengan komponen atau sub pokok bahasan yang harus ada dalam laporan karya ilmiah. Kesalahan pada pengorganisasian tulisan berkaitan dengan pengembangan gagasan dan cara mendukung gagasan. Bagian terpenting adalah kesalahan dalam pengembangan gagasan. Misalnya ketidak sesuaian judul, rumusan masalah, isis dan pembahasan yang seharusnya dikembangkan secara sistematis. Pernyataan yang bersifat kualitatif seharusnya didukung dengan data atau fakta yang disertakan kutipan atau referensi. Disamping itu unsur kalimat utama, kalimat penjelas dan kalimat penyimpul tidak terlihat jelas. Banyak ditemukan dalam satu paragraph hanya terdiri dari dua kalimat. Selain itu ditemukan pula beberapa kesalahan dalam mekanika penulisan seperti penggunaan ejaan, tanda baca, dan penyusunan kalimat. Berdasarkan kondisi tersebut perlu diupayakan perbaikan pembelajaran yang dapat meningkatkan kemampuan menulis laporan karya ilmiah remaja yakni melalui pendekatan kontekstual.

Identifikasi masalah dalam penelitian ini antara lain; rendahnya kemampuan siswa menulis laporan karya ilmiah, model pembelajaran yang digunakan guru kurang mendorong meningkatnya motivasi siswa untuk menulis, kurang tepatnya metode yang diaplikasikan selama proses pembelajaran. Berdasarkan identifikasi masalah tersebut maka dirumuskan masalah dalam penelitian ini sebagai berikut; bagaimana kemampuan menulis laporan karya ilmiah siswa kelas XII SMA Manba’ul Ullum sebelum menggunakan pendekatan kontekstual? Bagaimana peningkatan siswa kelas XII SMA Manba'ul Ullum setelah menggunakan pendekatan kontekstual dalam materi menulis laporan karya ilmiah remaja? Bagaimana respon siswa dalam materi menulis laporan karya ilmiah siswa kelas XII SMA Manba'ul Ullum?

Penelitian tindakan kelas (Classroom Action Research) biasanya dialakukan oleh guru di tempatnya mengajar dengan penekanan pada penyempurnaan atau peningkatan proses pembelajaran. Guru merencanakan perubahan yang akan dilakukan bersama observer lain sambil melakukan observasi, dan proses belajar berlangsung sesuai dengan jadwal belajar seperti biasanya. Jenis penelitian ini mampu menawarkan pendekatan dan prosedur baru yang lebih menjanjikan dampak langsung dalam bentuk perbaikan dan peningkatan profesionalisme guru dalam mengelola proses belajar mengajar dikelas

Pembelajaran kontekstual adalah pembelajaran yang menekankan pada proses keterlibatan siswa untuk dapat menemukan materi yang dipelajari dan menghubungkan dalam kehidupan nyata, sehingga mendorong siswa untuk dapat menerapkannya dalam kehidupan mereka. Pembelajaran kontekstual sebagai suatu model pembelajaran yang memberikan fasilitas kegiatan belajar siswa untuk mencari, mengolah, dan menemukan pengalaman belajar yang lebih bersifat konkret terkait kehidupan nyata melalui keterlibatan aktivitas siswa dalam mencoba, melakukan dan mengalami sendiri.

\section{Metode}

Jenis penelitian yang dilakukan adalah penelitian tindakan kelas (PTK) dengan dua siklus. Penelitian diputuskan menggunakan PTK karena diaksanakan di dalam kelas(laboratorium computer). Penelitian tindakan yang dilakukan bertujuan memperbaiki mutu praktik pembelajaran di kelas. Tujuan utama PTK adalah untuk memecahkan permasalahan nyata yang terjadi di kelas dan meningkatkan kegiatan nyata dalam kegiatan pengembangan profesinya. Penelitian ini berupaya memaparkan model pembelajaran kontekstual sebagai upaya meningkatkan kemampuan menulis laporan karya ilmiah remaja.

Subyek penelitian terdiri dari siswa kelas XII yang memiliki tugas akhir pembuatan karya ilmiah remaja sebanyak 40 siswa selama tiga bulan terhitung September hingga November. Terdapat dua jenis instrumen yang digunakan yakni kuantitatif dan kualitatif. Pelaksanaan PTK dilakukan selama 2 siklus. Setiap siklus terdiri dari 4 tahapan yakni perencanaan, Pelaksanaan, observasi dan evaluasi.

\section{Hasil dan Pembahasan}

Penelitian ini terdiri dari 2 siklus dengan masing masing siklus terdiri dari 4 tahapan yakni sebagai berikut:

\section{Siklus 1}

\section{Perencanaan}

Dalam tahap ini observer, pembimbing dan penguji duduk bersama untuk membahas rencana pelaksanaan pembelajaran penulisan laporan karya ilmiah remaja. Pembuatan rencana didasarkan pada kesalahan yang terdapat pada pertemuan sebelumnya. kesalahan dalam struktur tulisan, pengorganisasian tulisan, dan aspek mekanika penulisan masih banyak ditemui pada siswa. Oleh karena itu perlu diberikan penjelasan apa yang dimaksud dengan karya ilmiah remaja, bagaimana cara mengembangkan gagasan agar terjadi kesesuaian judul, isi, dan pembahasan, serta penjelasan bagaimana mekanika penulisan yang baik seperti cara mengutip, ejaan, tanda baca dan penulisan kalimat dalam paragraph. Semua disampaikan menggunakan pendekatan kontekstual.

\section{Pelaksanaan}


Kegiatan yang dilakukan dalam tahap ini adalah melaksanakan pembelajaran penulisan karya ilmiah seseuai dengan rencana yang telah di bahas pada fase sebelumnya. Dalam pelaksanaannya siswa dikumpulkan di laboratorium computer untuk mendengarkan penjelasan seputar karya ilmiah remaja dan cara pengembangan gagasan dalam sebuah laporan. Setelah dianggap paham siswa diminta duduk secara berkelompok didepan computer dan mulai diminta memperbaiki apa yang telah di tuliskan dalam penulisan sebelumnya. Dalam tahap ini siswa diijinkan bertanya apabila terdapat bagian yang tidak dimengerti. Pada akhir kegiatan siswa diminta mempresentasikan hasil penulisan untuk kemudian dilakukan penilaian.

\section{Observasi}

Pada tahap ini dilakukan observasi atau pengamatan selama penelitian berlangsung. Pada tahap ini para observer membuat cacatan lapangan mengenai setiap hal yang terjadi dalam pembelajaran. Catatan lapangan ini akan di jadikan bahan evaluai untuk perbaikan pada siklus selanjutnya jika nilai yang diperoleh belum baik.

\section{Evaluasi}

Tahap terakhir yang dilakukan pada siklus 1 adalah refleksi, yaitu mengkaji secera menyeluruh kegiatan dimulai dari perencanaan, pelaksanaan, observasi hingga dilakukan evaluasi. Evaluasi dilakukan dengan tujuan memperbaiki segala jenis kekurangan yang terdapat dari awal hingga akhir siklus. Jika hasil penilaian belum memnuhi syarat maka dilakukan siklus selanjutnya. Pada siklus 1 peningkatan yang sihgnifikan belum terlihat oleh karena itu dilakukan siklus selanjutnya. Dalam siklus 1 masih ditemui beberapa kesalahan yang sama tetapi sudah banyak berkurang dibanding sebelum diberikan penjelasan. Pada akhir siklus 1 diperoleh rata rata 78 yang artinya siklus belum dapat dihentikan atau menuju siklus selanjutnya. Penguji, pembimbing dan observer duduk bersama untuk mencari solusi untuk dijadikan perbaikan di siklus 2 .

\section{Siklus 2}

\section{Perencanaan}

Dalam tahap ini observer, pembimbing dan penguji duduk bersama untuk membahas rencana pelaksanaan pembelajaran penulisan laporan karya ilmiah remaja. Pembuatan rencana didasarkan pada hasil evaluasi pada siklus sebelumnya. kesalahan dalam struktur tulisan, pengorganisasian tulisan, dan aspek mekanika penulisan masih banyak ditemui pada siswa. Oleh karena itu perlu diberikan penekanan penjelasan apa yang dimaksud dengan karya ilmiah remaja, bagaimana cara mengembangkan gagasan agar terjadi kesesuaian judul, isi, dan pembahasan, serta penjelasan bagaimana mekanika penulisan yang baik seperti cara mengutip, ejaan, tanda baca dan penulisan kalimat dalam paragraph. Semua disampaikan menggunakan pendekatan kontekstual.

\section{Pelaksanaan}

Kegiatan yang dilakukan dalam tahap ini adalah melaksanakan pembelajaran penulisan karya ilmiah seseuai dengan rencana yang telah di bahas pada fase sebelumnya. Dalam pelaksanaannya siswa kembali dikumpulkan di laboratorium computer untuk mendengarkan penjelasan seputar karya ilmiah remaja dan cara pengembangan gagasan dalam sebuah laporan. Pada tahap ini kembali diberikan tekanan pada bagian bagian yang masih sering terjadi kesalahan. Setelah dianggap paham siswa diminta duduk secara berkelompok didepan computer dan mulai diminta memperbaiki apa yang masih belum tepat pada penulisan sebelumnya. Dalam tahap ini siswa diijinkan bertanya apabila terdapat bagian yang tidak dimengerti. Pada akhir kegiatan siswa diminta mempresentasikan hasil penulisan untuk kemudian kembali dilakukan penilaian.

\section{Observasi}

Pada tahap ini dilakukan observasi atau pengamatan selama penelitian berlangsung. Pada tahap ini para observer membuat cacatan lapangan mengenai setiap hal yang terjadi dalam pembelajaran. Catatan lapangan ini akan di jadikan bahan evaluai untuk perbaikan pada siklus selanjutnya jika nilai yang diperoleh belum baik.

\section{Evaluasi}

Tahap terakhir yang dilakukan pada siklus 1 adalah refleksi, yaitu mengkaji secera menyeluruh kegiatan dimulai dari perencanaan, pelaksanaan, observasi hingga dilakukan evaluasi. Evaluasi dilakukan dengan tujuan memperbaiki segala jenis kekurangan yang terdapat dari awal hingga akhir siklus. Jika hasil penilaian belum memnuhi syarat maka dilakukan siklus selanjutnya. Pada siklus 1 peningkatan yang sihgnifikan belum terlihat oleh karena itu dilakukan siklus selanjutnya. Dalam siklus 1 masih ditemui beberapa kesalahan yang sama tetapi sudah banyak berkurang disbanding sebelum diberikan penjelasan.

Perbandingan nilai dari sebelum tindakan saat siklus satu dan siklus dua disajikan dalam tabel.

Tabel 1. Daftar nilai Ujian Karya Ilmiah Remaja Oleh penguji

\begin{tabular}{llccc}
\hline No & Nama & \multicolumn{3}{c}{ Skor yang diperoleh } \\
\cline { 3 - 5 } & $\begin{array}{c}\text { Sebelum } \\
\text { siklus }\end{array}$ & $\begin{array}{c}\text { Siklus } \\
1\end{array}$ & $\begin{array}{c}\text { Siklus } \\
2\end{array}$ \\
\hline & $\begin{array}{l}\text { Alfah Al- } \\
\text { Chairiah }\end{array}$ & 70 & 75 & 80 \\
\hline & $\begin{array}{l}\text { Alya Nur } \\
\text { Faujiah }\end{array}$ & 70 & 75 & 80 \\
\hline
\end{tabular}




\begin{tabular}{|c|c|c|c|c|}
\hline 3 & $\begin{array}{l}\text { Alysia Naifah } \\
\text { Aileen }\end{array}$ & 65 & 70 & 80 \\
\hline 4 & $\begin{array}{l}\text { Amalia Zanuba } \\
\text { Fauziah }\end{array}$ & 85 & 90 & 85 \\
\hline 5 & $\begin{array}{l}\text { Ananda } \\
\text { Shabila }\end{array}$ & 65 & 70 & 80 \\
\hline 6 & $\begin{array}{l}\text { Andira Wulan } \\
\text { Doyya }\end{array}$ & 65 & 70 & 80 \\
\hline 7 & $\begin{array}{l}\text { Anggie Nur } \\
\text { Firdaus }\end{array}$ & 70 & 75 & 80 \\
\hline 8 & Ardita Hidayah & 70 & 75 & 80 \\
\hline 9 & $\begin{array}{l}\text { Ashifatul } \\
\text { Auliya }\end{array}$ & 65 & 70 & 80 \\
\hline 10 & $\begin{array}{l}\text { Aulia Maulida } \\
\text { Hamzah }\end{array}$ & 80 & 85 & 85 \\
\hline 11 & $\begin{array}{l}\text { Ayu Shofwah } \\
\text { Fathillah }\end{array}$ & 80 & 85 & 85 \\
\hline 12 & $\begin{array}{l}\text { Calista } \\
\text { Farahdiba R.V. }\end{array}$ & 65 & 70 & 80 \\
\hline 13 & $\begin{array}{l}\text { Chusnul } \\
\text { Azizah }\end{array}$ & 65 & 70 & 80 \\
\hline 14 & $\begin{array}{l}\text { Citra Sastra } \\
\text { Putri }\end{array}$ & 70 & 75 & 80 \\
\hline 15 & $\begin{array}{l}\text { Dea Amalia } \\
\text { Haris }\end{array}$ & 70 & 75 & 80 \\
\hline 16 & $\begin{array}{l}\text { Dela } \\
\text { Asokawati } \\
\text { P.A. }\end{array}$ & 65 & 70 & 80 \\
\hline 17 & $\begin{array}{l}\text { Delia Maulida } \\
\text { Az-Zahra }\end{array}$ & 65 & 70 & 80 \\
\hline 18 & $\begin{array}{l}\text { Della Fithria } \\
\text { Khairunnisa }\end{array}$ & 65 & 70 & 80 \\
\hline 19 & Dina Agustina & 75 & 80 & 85 \\
\hline 20 & $\begin{array}{l}\text { Dini Putri } \\
\text { Aprilia } \\
\text { Ningrum } \\
\end{array}$ & 75 & 80 & 77 \\
\hline 21 & $\begin{array}{l}\text { Dita } \\
\text { Azzahraneta }\end{array}$ & 80 & 85 & 82 \\
\hline 22 & Egi Damayanti & 75 & 80 & 77 \\
\hline 23 & $\begin{array}{l}\text { Elsa Permata } \\
\text { Juliana }\end{array}$ & 75 & 80 & 77 \\
\hline 36 & Elsifa Hayek & 75 & 80 & 80 \\
\hline 24 & $\begin{array}{l}\text { Fasya } \\
\text { Maharani Putri } \\
\text { Sofyan }\end{array}$ & 80 & 85 & 80 \\
\hline 25 & $\begin{array}{l}\text { Febi Yanti } \\
\text { Permata }\end{array}$ & 80 & 85 & 78 \\
\hline 26 & $\begin{array}{l}\text { Fina Ifadatus } \\
\text { Silmi }\end{array}$ & 80 & 85 & 83 \\
\hline 27 & $\begin{array}{l}\text { Firdha Aulia } \\
\text { Fatina }\end{array}$ & 80 & 85 & 78 \\
\hline 28 & $\begin{array}{l}\text { Harfiana } \\
\text { Fadillah }\end{array}$ & 80 & 85 & 88 \\
\hline 29 & $\begin{array}{l}\text { Hermalia } \\
\text { Fauziah }\end{array}$ & 75 & 80 & 78 \\
\hline 30 & Ines Almaida & 75 & 80 & 80 \\
\hline 31 & Ining Saputri & 77 & 82 & 85 \\
\hline 32 & Intan Raihan & 73 & 78 & 77 \\
\hline
\end{tabular}

\begin{tabular}{|c|c|c|c|c|}
\hline \multicolumn{5}{|c|}{ Nazlia } \\
\hline & Junilla Manisa & & 80 & 8 \\
\hline 33 & .F. & 75 & 80 & 80 \\
\hline 34 & Kharisma Elok & 75 & 80 & 77 \\
\hline 35 & Khoirunnisa & 75 & 80 & 78 \\
\hline 37 & $\begin{array}{l}\text { Kurniawati } \\
\text { Zakia Safitri }\end{array}$ & 75 & 80 & 80 \\
\hline 38 & $\begin{array}{l}\text { Laila } \\
\text { Rohmawati }\end{array}$ & 75 & 80 & 78 \\
\hline 39 & Laily Isnaini & 75 & 80 & 78 \\
\hline 40 & Lulu Alfina & 65 & 70 & 85 \\
\hline
\end{tabular}

Menghitung skor total rata-rata dari setiap siklus dengan menggunakan rumus:

$$
\bar{X}=\frac{\sum X}{n}
$$

Keterangan:

(Ngalim Purwanto, 2012)

$$
\begin{aligned}
& \bar{X}=\text { skor rata }- \text { rata tiap aspek } \\
& \sum X=\text { jumlah skor tiap aspek } \\
& n \quad=\text { jumlah nilai }
\end{aligned}
$$

Berdasarkan tabel di atas diperoleh rata rata nilai sebelum siklus 73, setelah siklus satu 78 dan pada siklus dua 80,4. Disajikan dalam tabel sebagai berikut:

Tabel 2 Perbandingan ketuntasan nilai sebelum dan setelah tindakan

\begin{tabular}{ll}
\hline Ketuntasan & Nilai \\
\hline Sebelum siklus & 73 \\
\hline Siklus 1 & 78 \\
\hline Siklus 2 & 80,4 \\
\hline
\end{tabular}

\section{Kesimpulan}

Berdasarkan paparan hasil dan pembahasan di atas dapat ditarik kesimpulan sebagai berikut:

1. Kemampuan siswa dalam menulis laporan penamatan sebelum menggunakan model pembelajaran kontekstual dan berdasarkan observasi sebanyak 40 sisiwa memiliki nilai rata rata 73 , sehingga diketahui kemampuan menulis laporan siswa masih rendah.. hal ini menunjukkan siswa belum memahami dengan baik cara menulis laporan. Maka dari itu perlu digunakan pendekatan kontekstual

2. Kemmapuan menyusun karya ilmiah remaja dapat ditingkatkan melalui pendekatan kontekstual. Peningkatan kemampuan menulis laporan karya ilmiah terjadi pada tahap pengembangan gagasan dimana siswa sudah lebih baik dalam menguhubungkan judul, isi dan pembahasan. Selain itu komponen komponen wajib yang harus ada dalam tiap bab sudah lebih di teliti. Ditinjau lebih lanjut diperoleh perbandingan sebelum tindakan 
memiliki nilai rata rata 73 , setelah siklus 1 diperoleh nilai rata rata 78 , dan setelah siklus 2 atau siklus terakhir diperoleh nilai 80,4 oleh karena itu siklus dihentikan.

3. Respon belajar siswa sangat tinggi dan baik setelah menggunakan model pembelajaran kontekstual, hal ini terlihat dari meningkatnya kemampuan siswa dalam menulis laporan pengamatan sebelum dan sesudah menggunakan model pembelajaran kontekstual.

\section{Daftar Pustaka}

Arsyad, A. (2014). Media Pembelajaran. Jakarta: PT RAJA GRAFINDO PERSADA.

Hamruni. 2012. Strategi Pembelajaran. Yogyakarta: Insan Madani. hal. 132

Iskandar. (2012). Psikologi Pendidikan (Sebuah Orientasi Baru). Jakarta: Gaung Persada Press Grup

Jamarnis, M. (2013). Orientasi Baru dalam Psikologi Pendidikan. Bogor: Ghalia Indinesia.

Kasimin, d. (2012). Media Pembelajaran : Teori dan Aplikasi (pertama ed.). yogyakarta: Trust Media Publishing.

Knight, Randall D.(2012). Physics For Scientists And Engineers. 484 http://www.wilwy.com/go/permissions.

Kunandar. 2012. Langkah Mudah Penelitian Tindakan Kelas. Jakarta: PT Raja Grafindo. hal.45

Kustandi, C. (2011). Media Pembelajaran Manual dan Digital. Bogor: Ghalia Indonesia.

Purwanto, Ngalim. 2012. Prinsip - Prinsip dan Teknik Evaluasi Pengajaran. Bandung: PT Remaja Rosdakarya.

Rusmala, Dewi. 2010. Profesionalisme Guru Melalui Penelitian Tindakan Kelas. Medan: Pasca Sarjana Unimed hal.13.

Rusman. 2012. Model-Model Pembelajaran. Jakarta: PT Raja Grafindo Persada, hal. 190

Salim, dkk. 2015. Penelitian Tindakan Kelas. Medan: Perdana Publishing. hal.23. 